\title{
Detection of Firmness in Intact Pumpkins and Sakurajima Radishes by Impact Forces
}

\author{
Jie Yu Chen, Mitsuru Miyazato, Etsuji Ishiguro and Naohiko Nanba \\ Faculty of Agriculture, Kagoshima University, Kagoshima 890
}

\begin{abstract}
Summary
The impact forces of the sample struck by hammer of a rigid sphere were studied as means for nondestructive determination of firmness. Impact forces were predicted with a simple elasticity model. Model results showed that the shape characteristic $\mathrm{k}$ (peak force/impulsion ${ }^{6 / 5}$ ) of the impact force solutions can be used to predict firmness. Because it was sensitive to changes in elasticity of sample and completely insensitive to the speed at contact and variations in size of samples.

On experimental apparatus with intact pumpkins and Sakurajima radishes, the correlation coefficients between the impact characteristic $K$, and flesh firmness of pumpkins and Sakurajima radishes measured by a penetrometer were 0.93 , and 0.92 respectively and hence, these results showed that the method was suitable for determining firmness of pumpkins and Sakurajima radishes.
\end{abstract}

\section{Introduction}

Firmness is an important physical property that is often used for evaluating the quality of fruits and vegetables. In many agricultural products, firmness is related to maturity and internal quality. For example, firmness of pumpkin increases gradually as it become more matured and firmness of Sakurajima radish changes as it become brood radish. Thus, firmness can be used as a criteria for sorting different maturity pumpkins and also for discriminating internal quality of Sakurajima radish.

At present, no commercial equipment is used for nondestructive firmness sorting of pumpkins and Sakurajima radishes. However, the potential for firmness sensing techniques have been investigated in the past for other fruits and vegetables. Garrett and Furry (1972) used measurements of the velocity of sonic pulses through apple flesh to predict the modulus of elasticity. Finney (1971), Clark and Shackelford (1973), Bower et al. (1976), and Armstrong et al. (1990), measured mechanical vibration as means of predicting peach flesh firmness. Perry (1977) and Mehlschau et al. (1981) de-

Received for publication 9 October 1992. veloped systems for recording force and deflection data on peaches and pears, respectively. Those methods could be used to distinguish immature and over mature fruits from threshold of mature fruit. But application of these techniques to an automatic sorting system was limited by the need for complicated fruit handling or the coupling of surface transducers. Due to these factors, a single lane impact force response firmness sorter was developed (Delwiche et al., 1987, 1989, 1991). The criteria for determining the firmness of fruits was sensitive to the variability in fruit mass and radius of curvature at the contact point and especially, the speed at contact. It was possible to be confounding the variations in impact force response due to flesh firmness.

In order to reduce these effects and to increase the accuracy of firmness prediction, a firmness sorting method of impulse hammer type without any limitation and orientation was investigated.

\section{Materials and Methods}

\section{Materials}

Pumpkins used in this study were harvested during the summer of 1991 from the area of Kaseda town, Kagoshima prefecture, Japan. And Sakuraji- 


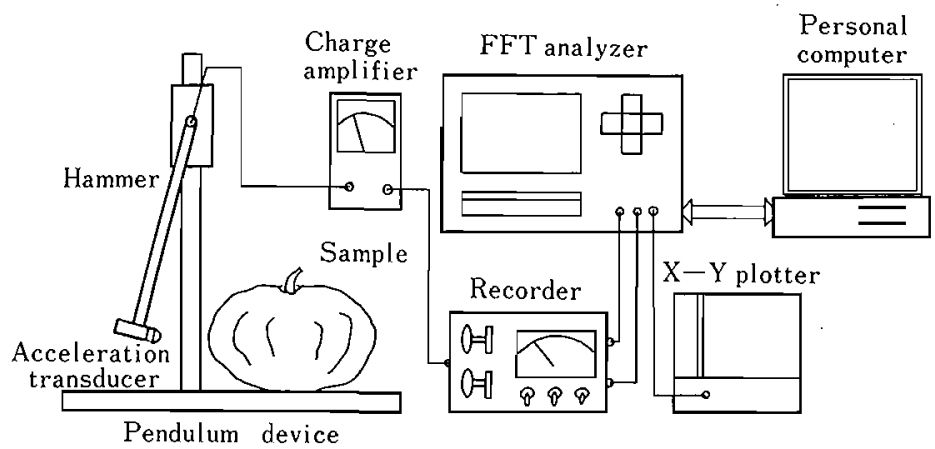

Fig. 1. Schematic diagram of a hammer type striking apparatus and an accelerated transducer.

ma radishes were harvested from the area of Sakurajima, Kagoshima prefecture, Japan. After harvest, basic physical properties, like mass(g), density $(\rho)$, diameter $(\mathrm{cm})$ and firmness $(\mathrm{kg})$, and impact force responses were measured immediately. Flesh firmness was measured by using hand penetrometer with a tip of $12 \mathrm{~mm}$ diameter (Model $\mathrm{KMH}-51$, made in Japan).

\section{Apparatus and methods}

Schematic diagram of the experimental apparatus is shown in Fig. 1. Pendulum device was used in the striking part of the experimental apparatus. It was possible to change striking velocity when the falling angle of the pendulum was changed. It was made of a striking sphere hammer $(R=7 \mathrm{~mm})$. Accelerated transducer (Model PH-51) was mounted in the striking sphere hammer. The leg length of pendulum was $35 \mathrm{~cm}$ and it's total mass was $205 \mathrm{~g}$. The fulcrum of the pendulum was easily changed to set up and down, so it was very easy to do experiments.

Samples were kept on the pendulum device of experimental apparatus and the pendulum with the striking sphere was allowed to fall on the samples from established angle. The impact forces were measured by accelerated transducer holding in pendulum. The transducer output was amplified through charge amplifier (Model NM-27) and sampled at $1 \mathrm{kHz}$ by FFT analyzer (Model CF-920S) and stored in microcomputer memory (Model PC-9801DX).

\section{Results and Discussion}

\section{Impact model and analysis}

In the case of a small sphere horizontally striking on other sphere (sample), the application of Newton's second law gives

$$
\mathrm{m} \frac{\mathrm{d}^{2} \mathrm{x}}{\mathrm{dt^{2 }}}=-\mathrm{f}
$$

where $\mathrm{x}$ is the approach (distance) of the sphere center to another sphere (sample) center, $m$ is the striking sphere mass, $\mathrm{f}$ is the contact force.

Assuming striking sphere to be significantly harder and smaller in radius of curvature than the elastic sphere (sample), and using an elastic contact theory (Timoshenko and Goodier, 1970), the impact force between the striking sphere and sample is related to the approach by

$$
\mathrm{f}=\alpha \mathrm{x}^{3 / 2}
$$

and $\alpha$ is related to parameters by equation (3)

$$
\alpha=\frac{4}{3} \frac{\mathrm{R}^{1 / 2} \mathrm{E}}{\left(1-\mu^{2}\right)}
$$

where $\mathrm{R}$ is the radius of curvature of striking sphere, $\mathrm{E}$ is flesh elasticity of sample, $\mu$ is poisson's ratio.

Substituting equation (2) into equation (1), and integrating over $\mathrm{x}$ with the initial condition $\mathrm{x}_{(0)}=0$, $\mathrm{dx} / \mathrm{dt}_{(0)}=\mathrm{v}$, the governing equation for $\mathrm{x}$ is

$$
\frac{\mathrm{dx}}{\mathrm{dt}}=\left[\mathrm{v}^{2}-\frac{4 \alpha}{5 \mathrm{~m}} \mathrm{x}^{5 / 2}\right]^{1 / 2}
$$

where $\mathrm{v}$ is the speed at the moment of impact. 
Substituting the standard physical values of the sample (elasticity $\mathrm{E}$ is $1 \mathrm{MPa}$, poisson's ration $\mu$ is 0.25 ) into equations (3) and (4), the relationship of the approach and impact time was solved numerically by using 4th order Runge-Kutta algorithm and then, using the equation (2), the relationship between the impact force and time was obtained. The solution of equation (2), (3) and (4) for the parameter values given is shown with the intermediate line in Fig. 2. The peak impact force was approximately $65 \mathrm{~N}$ and a contact time was 6.4 ms.

As the impact velocity does not change and the sample elastic modulus increases (elasticity $\mathrm{E}$ is 1.4 MPa), the solution of impact force is shown with the sharp line in Fig. 2. The same solutions decreased elasticity ( $E$ is $0.7 \mathrm{MPa}$ ) is shown with the flat line in Fig. 2. As the sample elastic modulus decreases, the peak impact forces become smaller and the contact times increase.

By using experimental apparatus, the actual impact forces were measured (Fig. 3) for three different firmness values of pumpkins (firmness were $0.75,0.58$ and $0.45 \mathrm{~kg}$ respectively). Comparison of the model solutions (Fig. 2) with actual impact force measurements of samples (Fig. 3) shows that the model impact force curved lines coincide with measured ones nearly. Therefore, the model used to study the impact force response was judged to be adequate for the objectives of this research.

Besides, if the impact velocity was not changed, the peak impact force was one of the possible criteria for determining the firmness of samples. However, it was brought that it was difficult to hold the definite impact velocity for actual operating.

\section{Shape characteristics and measurements of firmness}

When the physical values of sample does not change, and the impact velocity changes up and down, the solutions of equations (2), (3) and (4) for the different impact velocities are shown in Fig. 4. The change of the impact velocity brought the impulsion changes as well as the peak impact force changes. Therefore, using the two important parameters, peak force and impulsion, it was possible to obtain the criteria for determining the firmness of samples with no concern in the impact velocity.

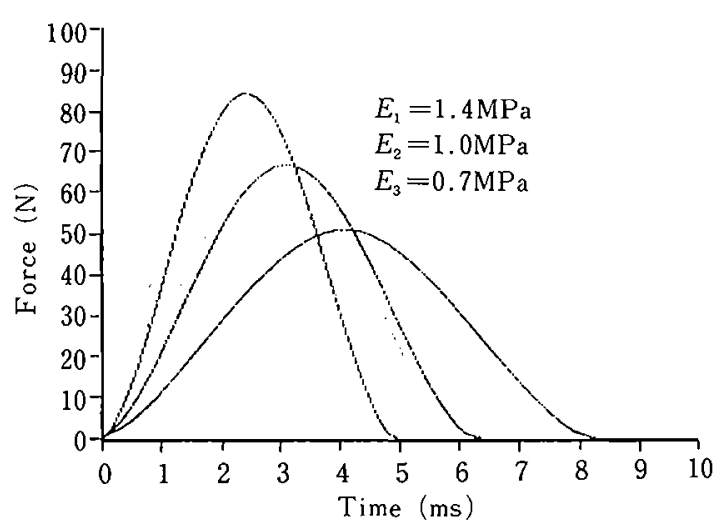

Fig. 2. Simulated impact forces for pumpkins of different firmness.

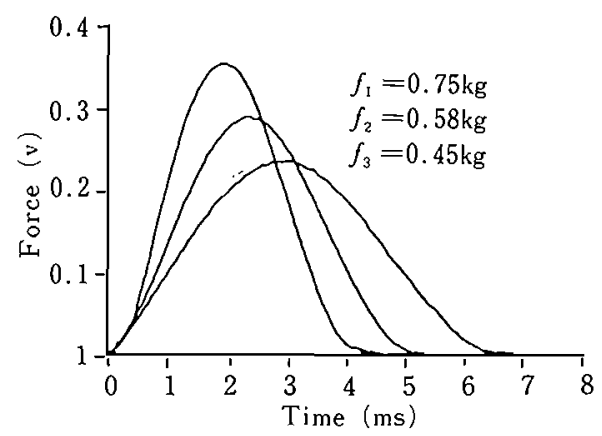

Fig. 3. Impact forces measured with pumpkins of different firmness.

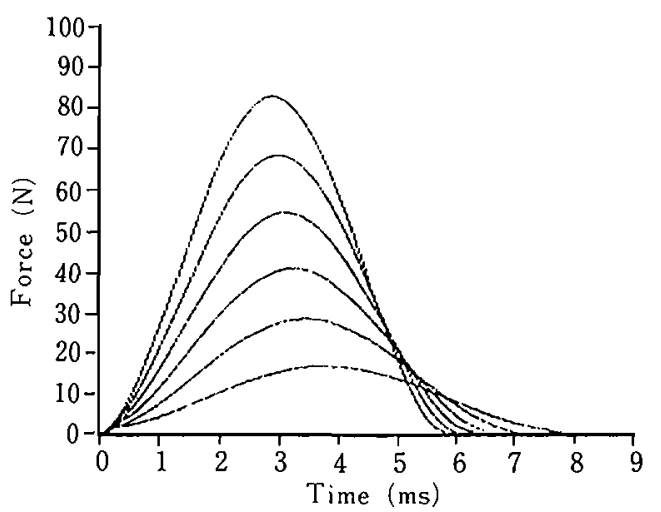

Fig. 4. Simulated impact forces for pumpkins under different impact velocities. 
For the equation (4), by setting $\mathrm{dx} / \mathrm{dt}=0$ the peak approach $x_{p}$ is given by

$$
\mathrm{x}_{\mathrm{p}}=\left(\frac{5 \mathrm{~m}}{4 \alpha}\right)^{2 / 5} \mathrm{v}^{4 / 5}
$$

and the peak force $\mathrm{fp}$ is given by too

$$
\mathrm{f}_{\mathrm{p}}=\left(\frac{5}{4}\right)^{3 / 5} \mathrm{~m}^{2 / 5} \alpha^{2 / 5} \mathrm{v}^{6 / 5}
$$

Moreover, the impulsion s, that is the sum product values of the impact force and the time from first contact to detached contact, is shown by

$$
\mathrm{s}=\int_{0}^{2 \mathrm{tp}} \mathrm{fdt}=2 \mathrm{mv}
$$

From equation (6) and (7), it was easy to understand that the peak force was related to the $\mathrm{v}^{6 / 5}$ as well as the physical values of sample such as elasticity and the impulsion was related to the impact velocity $\mathrm{v}$ too. So the following characteristic $\mathrm{k}$ based on the peak impact force fp and the impulsion $s$ was considered.

$$
\mathrm{k}=\frac{\mathrm{f}_{\mathrm{p}}}{\mathrm{s}^{6 / 5}}
$$

Substituting these equation (3), (6) and (7) into equation (8), the characteristic $\mathrm{k}$ was given by

$\mathrm{k}=\left(\frac{5}{16}\right)^{3 / 5}\left(\frac{4}{3}\right)^{2 / 5} \mathrm{~m}^{-2 / 5} \mathrm{R}^{1 / 5}\left(\frac{\mathrm{E}}{1-\mu^{2}}\right)^{2 / 5}$

In equation (9), the striking mass $m$ and its radius $\mathrm{R}$ were definite and known. Therefore the front part of equation (9), that is $(5 / 16)^{3 / 5}(4 / 3)^{2 / 5} m^{-3 / 5} R^{1 / 5}$, was replaced with a constant $\mathrm{c}$ and equation (9) was given by

$$
\mathrm{k}=\mathrm{C}\left(\frac{\mathrm{E}}{1-\mu^{2}}\right)^{2 / 5}
$$

Equation (10) shows the dependence of the timedomain impact force characteristic $\mathrm{k}$ on the sample and its physical values, that is elasticity and poisson's ratio. In other word, the impact force characteristic $\mathrm{k}$ was sensitive to changes in the elastic modulus and poisson's ratio and insensitive to impact velocity and variations in sample size. Therefore, it was suitable criteria for determing the firmness of those products.

Besides, actual impact forces were measured. The relationship of the impact peak force $\mathrm{fp}$ and the impact force impulsion $\mathrm{s}^{6 / 5}$ is shown in Fig. 5 with pumpkins and Sakurajima radishes corresponding to the different impact velocity, that was obtained by falling angle of the pendulum in the experimental apparatus.

The impact force impulsion $\mathrm{s}^{6 / 5}$ increased as the peak impact force $f p$ increased and the impulsion $\mathrm{s}^{6 / 5}$ was highly correlated with the peak force fp, its correlation coefficient was 0.998 . Besides, the plotted pots between the fp and $s^{6 / 5}$ were crossed nearly through the origin, in other words, actual measurements show that the radio of the peak force $\mathrm{fp}$ to the impulsion $\mathrm{s}^{6 / 5}$ was not related with the impact velocity and was definite value. The result obtained theoretically agreed with the actual measurements with experimental apparatus.

To examine the number of tested pumpkins and Sakurajima radishes with the experimental apparatus, the actual characteristics $\mathrm{K}$ was plotted against penetrometer measurements of flesh firmness. The flesh firmness measured with penetrometer increased as the $\mathrm{K}$ increased. But the linear equation did not fit with the curvilinear trends in the data and a logarithmic transformation provided a better result. The equation format and required transformations were:

$$
\begin{aligned}
& \mathrm{K}=\mathrm{AH} \mathrm{H}^{\mathrm{B}} \\
& \operatorname{Ln}(\mathrm{K})=\operatorname{Ln}(\mathrm{A})+\mathrm{B}[\operatorname{Ln}(\mathrm{H})]
\end{aligned}
$$

Where $\mathrm{H}$ is the firmness measured with penetrometer, $\mathrm{K}$ is the characteristic measured with the experimental apparatus, $\mathrm{A}$ and $\mathrm{B}$ is unknown constant to be determined using regression.

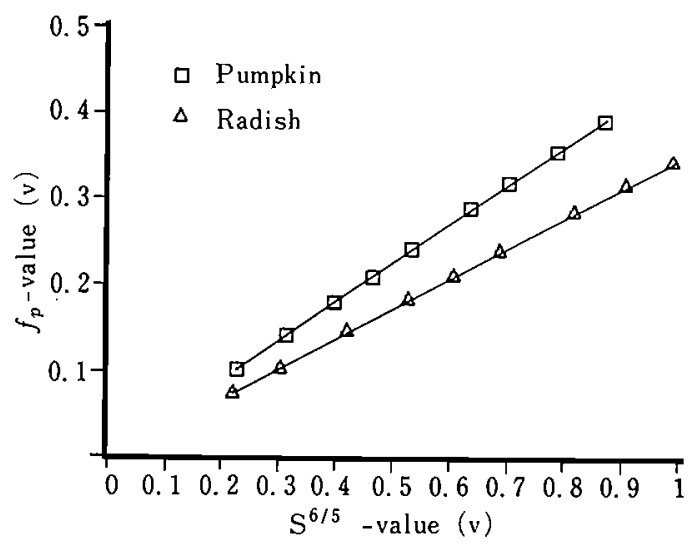

Fig. 5. Relationship between the fp-value and $S^{6 / 5}$-value of pumpkins and radishes. 
Results for the regression analysis using pumpkins of 38 and Sakurajima radishes of 88 respectively paired observations produced the following equation:

$$
\begin{aligned}
& \mathrm{K}=0.515 \mathrm{H}^{0.591} \\
& \mathrm{~K}=0.521 \mathrm{H}^{0.585}
\end{aligned}
$$

In the event that the characteristic $K$ was to be used to estimate flesh firmness of pumpkins and

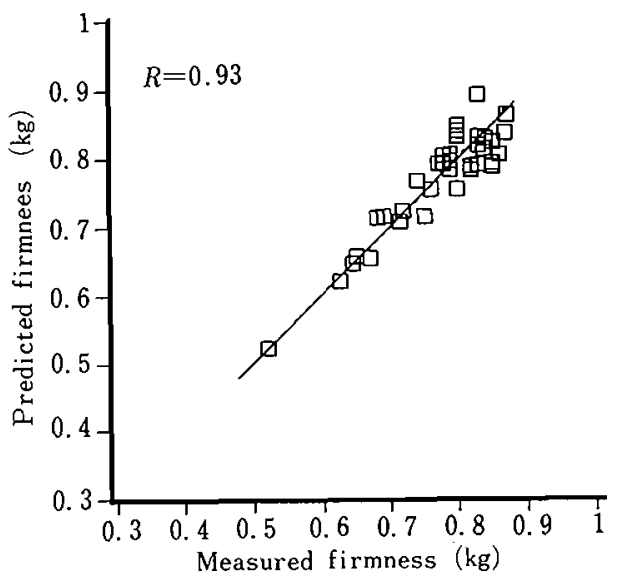

Fig. 6. Comparison of pumpkin's firmness predicted by the impact technique and those obtained by the penetrometer measurement.

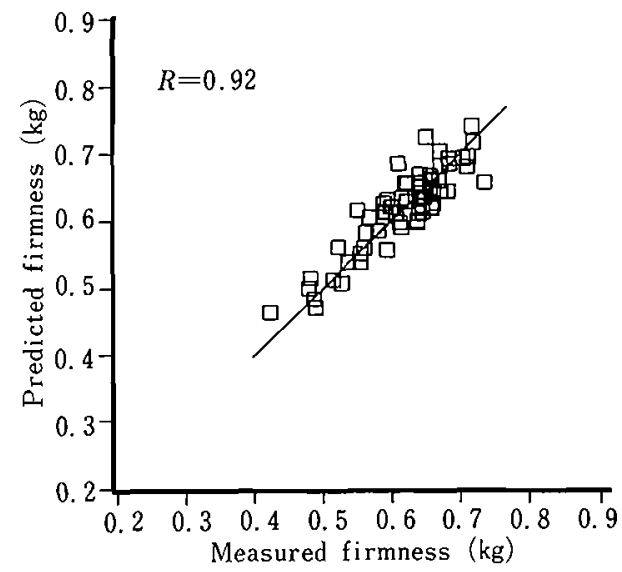

Fig. 7. Comparison of radish's firmness predicted by the impact technique and those obtained by the penetrometer measurement.
Sakurajima radishes, the relationship was:

$$
\begin{aligned}
& \mathrm{H}=3.032 \mathrm{~K}^{1.692} \\
& \mathrm{H}=3.049 \mathrm{~K}^{1.709}
\end{aligned}
$$

From equations (15) and (16), the flesh firmness was found to be a function of the square of characteristic $\mathrm{K}$ approximately. It seems reasonable that the flesh firmness should be related to the characteristic $\mathrm{K}$ measured with the experimental apparatus.

Figs. 6 and 7 show a plot of estimated flesh firmness, using the characteristic $\mathrm{K}$ in equation (15) and (16), against the flesh firmness measured with a penetrometer. Comparison of the firmness values obtained by impact force and penetrometer showed that two methods gave extremely close results and hence, showed that the method of using the characteristic $\mathrm{k}_{\mathrm{p}}$ of impact force seemed to be suitable for determining firmness of intact agricultural products such as pumpkin and Sakurajima radish.

\section{Acknowledgements}

We express our appreciation to Mr. B. Muthuvelan for his critical reading the manuscript and to Takakazu Miyahara for his assistance for samples.

\section{Literature Cited}

Armstrong, P., H.R. Zapp and G.K. Brown. 1990. Impulsive excitation of acoustic vibrations in apples for firmness determination. Trans. of the ASAE 33(4) : 1353-1359.

Bower, D. R. and R.P. Rohrbach. 1976. Application of vibrational sorting to blue berry firmness separation. Trans. of the ASAE 19(1): 185-191.

Clark, R. L. and P.S. Shackelford. 1973. Resonance and optical properties of peaches as related to flesh firmness. Trans. of the ASAE 16(6): 1140-1142.

Delwiche, M.J., T. Mcdonald and S.V. Bowers. 1987. Determination of peach firmness by analysis of impact forces. Trans. of the ASAE 30(1) : 249-254.

Delwiche, M.J., S. Tang and J.J. Mehlschau. 1989. An impact force response fruit firmness sorter. Trans. of the ASAE 32(1): 321-326.

Delwiche, M.J. and Y. Sarig. 1991. A probe impact sensor for fruit firmness measurement. Trans. of the ASAE 34(1) : 187-192.

Finney, E.E. 1971. Random vibration techniques for nondestructive evaluation of peach firmness. J. Agr. Eng. Res. 16(1) : 81-87. 
Garrett, R.E. and R.B. Furry. 1972. Velocity of sonic pulses in apples. Trans. of the ASAE 15(4) : 770-774.

Mehlschau, J. J., P. Chen, L. L. Claypool and R. B. Fridley. 1981. A deformeter for nondestructive maturity detection of pears. Trans. of the ASAE 24(5) : 1368-1371.
Perry, J.S. 1977. A nondestructive firmness (NDF) testing unit for fruit. Trans. of the ASAE 20(4) : 762-767.

Tomoshenko, S.P. and J.N. Goodier. 1970. Theory of elasticity. 3rd ed. McGraw-Hill Book Co., New York.

\section{打撃力によるカボチャと桜島大根硬度の非破壊測定}

陳 介余・宮里 满・石黒悦爾・難波直彦

鹿児島大学宸学部 890 鹿児島市郡元

摘要

本報では打慗力による脤産物の硬度を非破壊的に湘 定する方法を提案した。簡単な弾性モデルを用いて打 紫力を解析した結果, 特性值 $\mathrm{k}$ は莀應物の弹性係数な どの内部品質だけに影響され，寝産物の大きさと打絮 力の強さに影嘅されないので装産物硬度の判定指標と することが可能であることが示された。
また，力ボチャと桜島大根を供試材料として，打繁 装置を利用して統計的な実験をした結果，その硬度と $\mathrm{k}$ 値との間にそれぞれ0.93,0.92の相関係数が得られた. 従って, 本方法はカボチャと桜島大根の硬度を非破壊 测定するには可能だと思われる. 